\title{
Origin and Significance of the Research on Political Activities of the Communist Party of China in Yan'an Period
}

\author{
Kai Zhao \\ Marxism School, Sichuan University, Chengdu, 610207, China
}

\begin{abstract}
Keywords: Yan'an period, The Communist Party of China, Political activities of party
\end{abstract}
\begin{abstract}
Scientific and healthy political activity of party is the prominent organizational advantage of the Communist Party of China and the basic guarantee for maintaining the party's advanced nature and purity. It is also an important weapon for scientific decision-making and concerted efforts to tackle difficulties. A thorough study of the theoretical exploration and practical experience of the Communist Party of China in strengthening and standardizing the political activities of the party in Yan'an period has important enlightenment significance for strengthening the construction and improving the quality of inner-party political life in the new era.
\end{abstract}

Since the founding of the Communist Party of China, the CPC has attached great importance to the political life within the party. In Yan'an period, with the proposition of continuously pushing forward the Sinicization of Marxism, the construction of the Party became a great project, and the political life within the Party was highly valued as an inherent meaning of the great project. During the Yan'an period, the ideological and theoretical achievements of the Inner-party political Life of the Communist Party of China were constantly enriched, and many valuable experiences were formed in the practice of Inner-party political life. The basic norms of Inner-party political life were initially formed, and inner-party political life was gradually politicized and scientized.

\section{Research Origin of Political Activities of the Communist Party of China in Yan'an Period}

Since the 18th National Congress, the Party Central Committee, with Comrade Xi Jinping as its core, has placed more prominent emphasis on serious Inner-party political Life and purifying Inner-party political ecology. General Secretary $\mathrm{Xi}$ Jinping has published many important expositions on serious Inner-party political Life from a comprehensive perspective of the strategic layout of strict governance of the Party. On October 18, 2017, Xi Jinping pointed out in his report to the Nineteenth National Congress of the Communist Party of China that "the Party's political construction should be put in the first place", "the Party's Constitution should be respected, certain rules of political life within the Party should be strictly implemented under the new situation, and the political, epochal, principled and militant nature of political life within the Party should be enhanced. Resist the erosion of the principle of commodity exchange to inner party life and create a good political ecosystem with a clear atmosphere. From October 24 to 27, 2016, the Sixth Plenary Session of the Eighteenth Central Committee of the Communist Party of China, with the theme of promoting comprehensive and strict governance of the Party in depth, deliberated and adopted the "Several Guidelines for Political Life within the Party under the New Situation" and the "Regulations on Supervision within the Party of the Communist Party of China". The Plenary Session paid special attention to the problem-oriented and serious political life within the Party, emphasizing on the It is a scientific summary and theoretical sublimation of our Party's rule of governing the Party to carry out the Inner-party political life well under the new situation and to complete the systematic construction of the Inner-party political Life in theory. It is also a fundamental follow-up to the serious Inner-party political Life and purifying the Inner-party political Ecology under the new situation. On July 1, 2016, in a speech celebrating the 95th anniversary of the founding of the Communist Party of China, Xi Jinping pointed out that "serious political life within the Party is the basis for the comprehensive and 
strict administration of the Party. If the Party wants to control the Party, it must first start with the political life within the Party, and if it is to be strictly governed, it must start with the political life within the Party. We should strengthen and standardize the political life within the Party, strictly enforce the Party's political discipline and rules, enhance the political, epochal, principled and combat nature of the political life within the Party, and comprehensively purify the political ecology within the Party. On June 28, 2016, the Political Bureau of the Central Committee of the Communist Party of China stressed in its 33rd collective study on serious Inner-party political Life and purifying Inner-party political Ecology that "to carry out serious Inner-party political life is a fine tradition of our Party. Since its founding, our Party has attached great importance to political life within the Party. In its long-term practice, it has gradually formed a basic norm of political life within the Party with the main contents of seeking truth from facts, integrating theory with practice, closely linking with the masses, criticism and self-criticism, democratic centralism and strict Party discipline. To live and purify the Inner-party political Ecology is an essential part of the great struggle and great project. It is an important magic weapon for our party to adhere to the nature and purpose of the party. It is also an important way for our party to achieve self-purification, self-improvement, self-innovation and self-improvement. On October 29, 2015, Xi Jinping emphasized in his speech at the second plenary meeting of the Fifth Plenary Session of the eighteenth Central Committee that "there can be no political interest groups of all kinds within the Party, nor can there be any political interest groups that collude with each other within the Party and trade power and money with each other outside the Party. The Party Central Committee firmly opposes corruption, that is, it is necessary to prevent and eliminate the influence of such illegal interests on the Party's political life and restore the Party's good political ecology. The earlier, the more resolute and thorough the work is, the better it will be.

The Communist Party of China has always attached importance to the issue of political life within the Party, and has repeatedly stressed the strengthening and standardization of political life within the Party in the practical process of leading China's revolution, construction, reform and development. Our Party first began to use the concepts of "Party life" and "inner-Party life" in 1926 in the Party's documents. The Party's Party branch organization and its plans, originally published in the "School Journal" on May 15, 1926. In the report of the Sixth Plenary Session of the Sixth Central Committee of the CPC in 1938, "The Position of the Communist Party of China in the National War", Mao Zedong expounded for the first time the "four obedience" of democratic centralism and put forward requirements on how to carry out democratic centralism in the Party's life. "On the one hand, it really enlarges democratic life in the Party; on the other hand, it does not go far enough. In the extreme democratization, to break the discipline of laissez faire. In the Summer Situation of 1957, Mao Zedong put forward the general goal of political life within the Party and the state. "Our goal is to create a political situation that is both centralized and democratic, both disciplined and free, with unified will and individual ease of mind and liveliness, which is conducive to society." Socialist revolution and socialist construction. Deng Xiaoping has many important opinions on strengthening and regulating Inner-party political life, especially in his speech at the Second Plenary Session of the Twelfth Central Committee in 1983. Deng Xiaoping emphasized that "Party consolidation should not go through the motions", "Party spirit should be strengthened through ideological education", "leading cadres at all levels, especially senior cadres, should abide by the Party Constitution and abide by it." Some guidelines on political life within the party play an exemplary role. This is another important sign that the party is not going through the motions. " In July 1991, in celebrating the 70th anniversary of the founding of the Communist Party of China, Jiang Zemin stressed that "the principle of commodity exchange must not be introduced into the political life within the Party." In January 1997, Jiang Zemin further put forward the requirement that "all Party organizations at all levels should strictly abide by the inner-Party life" in his speech at the plenary session of the Central Discipline Inspection Commission. The two concepts of organizational life and strict intra-Party life are interoperable and mutually applicable, which have become the basic requirements of the great new project of promoting the Party's construction under the new situation. At the same time, our Party began to pay attention to strengthening the construction of intra-Party laws and regulations, and clearly put forward the requirement of "institutionalization and standardization of intra-Party life". 
The 15th Party Congress The report fully affirmed the achievements in this area, and "new steps have been taken to institutionalize and standardize inner party life." In November 2012, Hu Jintao stressed in his report to the 18th National Congress of the Party that "Party organizations at all levels and Party members, cadres, especially leading cadres, must consciously abide by the Party Constitution, consciously act in accordance with the Party's organizational principles and the Party's political living standards, and no one can be above the organization." It should not be ignored that since the founding of the Communist Party of China, great importance has been attached to the political life within the Party, and the Leaders' understanding of the political life within the Party has kept pace with the times and innovated with the development of practice.

\section{Research Significance of Political Activities of the Communist Party of China in Yan'an Period}

The Yan'an period is an important turning point for the Communist Party of China from childhood to maturity, from inadequate theoretical preparation to the realization of Marxism in China, from partial ruling to national ruling. The scientific and healthy political life within the Party is also starting from Yan'an. It strengthens the study and summary of the theoretical achievements and practical experience of the CPC's political life within the Party in the Yan'an period. Its theoretical value and practical significance are very prominent.

\subsection{Theoretical Value}

First, deepen the study of Sinicization of Marx doctrine. In Yan'an period, the Communist Party of China formally put forward the historical proposition of "Sinicization of Marxism" and scientifically answered it through its own practice. In October 1938, Mao Zedong pointed out in the Political Report on the New Stage of the Sixth Plenary Session of the Sixth Central Committee of the Communist Party of China: "To talk about Marxism without Chinese characteristics is only abstract and hollow Marxism. Therefore, the Sinicization of Marxism, so that in each performance with the necessary Chinese characteristics, that is, according to the characteristics of China to apply it, has become an urgent need for the whole party to understand and solve the problem. Strengthening the construction of Inner-party political Life and constantly improving the quality and level of Inner-party political life are the eternal theme and important magic weapon of the Party's construction, as well as the extremely important component of the Sinicization of Marxism. During this period, the theoretical innovation and practical experience of strengthening and standardizing the formation of Inner-party political life further enriched and developed the Marxist theory of Party building. Under the conditions of partial ruling, the Communist Party of China strengthened and standardized Inner-party political life, and made Inner-party political Life on the track of normalization and gradually formed the basis of Inner-party political life. This norm has opened a new situation of political life within the Party and successfully opened a new way of managing the Party in line with the requirements of the times and the conditions of the Party. From the perspective of local governance, combing the historical facts of the normalization of political life within the Party in Yan'an period and summarizing the relevant theoretical achievements and practical experience will help deepen the understanding of the historical process and theoretical achievements of Marxism in China and deepen the study of Marxism in China.

Secondly, it helps to enrich and innovate the main theories of the party's political life in the new era. In the new era, the practice of Inner-party political life is broad and flexible. In contrast, the perfection and innovation of Inner-party political life theory lags. The scientific and healthy political life within the Party started in Yan'an. It is precisely because the political life within the Party was constantly strengthened and standardized in the Yan'an period that the Party's construction became a "magic weapon" worthy of the name. Only then did the Party make clear that the Communists connected with the flesh and blood of the Chinese nation must serve the people wholeheartedly to make the Party perfect the Democratic centralism. Only when Party discipline is seriously strengthened can the Party form three fine styles of work, namely, integrating theory with practice, 
closely linking the masses and self-criticism, and a strict self-discipline mechanism, can the whole Party be closely united around the Party Central Committee with Mao Zedong as its core, and can the revolution under the leadership of the Party be fundamentally guaranteed a historic and great victory. The construction of Inner-party political life itself has a development thread of the same origin. In Yan'an period, especially the inner-party leaders represented by Mao Zedong made a series of expositions and theoretical exploration on strengthening and standardizing Inner-party political life. These theoretical achievements further enrich and expand the theoretical content of Inner-party political Life in the new era. Therefore, systematically combing the main contents and thoughts of the related works, reports, expositions and documents of the leaders of the Party in Yan'an period can further enrich and innovate the theoretical contents of the political life within the Party in the new era.

Finally, it further enriches the theoretical and practical research on the political life of the party in the Yanan period. The research on the history of Yan'an period has always been a hot spot in academic circles, including political, economic, cultural, social and many other aspects, but the research on the political life within the Party in Yan'an period is a matter of recent years, so there is not much research on this aspect. One is that there are no special works on political life within the Party in Yan'an period officially published in academic circles; the other is that there are few articles published in authoritative core journals; the third is that there is only one master's and doctoral dissertation on the retrieval of political life within the Party in Yan'an period.

\subsection{Practical Significance}

First, it is conducive to strengthening the construction of Inner-party political Life in the new era and improving the quality and level of inner-party political life to provide basic guidance. Serious inner party-political life is the party's fine tradition and political advantage. It has the same vein of development. General Secretary Xi Jinping once pointed out that "we should inherit and innovate, inherit and carry forward the fine tradition of Inner-party political life, at the same time based on the new reality, constantly improve and innovate, be good at guiding new practice with new experience, and better play the role of inner-party political life function". The study and summary of the political life within the Party in Yan'an period is of great practical significance to promote the comprehensive and strict administration of the Party and to strengthen the political life within the Party in the new era. Strengthening the construction of Inner-party political life has always been the focus of Party building. We should grasp the consistent theme, content, task and goal of Inner-party political life, outline the logical framework of serious Inner-party political life, avoid the vulgarization, arbitrariness and flatness of Inner-party political life, and do two things: first, in practice. The two is to innovate in succession. The historic investigation of the political life within the Party in the Yan'an period aims to better grasp the basic follow-up and logical framework of the serious political life within the Party in the new era, grasp the new tasks and missions of the political life within the Party, and provide reference and guidance for the further development of the practice of the serious political life within the Party in the new era.

Secondly, it is conducive to thinking about the goal orientation of the current Inner-party political Life from a strategic point of view and promoting the inheritance and innovation of Marxist theory of Party building in the Inner-party political life. Marxist theory of Party building has been used and developed since the founding of the Communist Party of China until the proposition of Sinicization of Marxism was put forward in Yan'an Period, which makes the theory of Party building of Marxism closely combine with the self-construction of the Communist Party of China and further promote the self-construction of the Party. Looking back on history, the Yan'an period is an important stage for the development of Marxist theory of Party building in China, and an important stage for the normalization of Inner-party political life. During this period, the important thoughts, activities, basic norms, institutional mechanisms, and objectives and tasks of the continuous exploration and formation of inner-party political life are all important. Under the guidance of Marxist theory of Party building, one of the core achievements in strengthening and standardizing Inner-party political Life at this stage is to strengthen the theoretical study of Party members and cadres, always stress the guiding position of Marxism, and establish the scientific belief of Marxism. Mao Zedong pointed out in his 
report "Reforming Our Learning" in Yan'an Period that "only when subjectivism is overthrown will the truth of Marxism-Leninism rise, the Party spirit consolidate, and the revolution triumph". At the Seventh National Congress of the Party in 1945, Liu Shaoqi pointed out in his report on the revision of the Party Constitution that it is the duty of every Communist Party member to strive to understand the basis of Marxism-Leninism and Mao Zedong Thought. From the past to the present, more than 70 years later, we have always adhered to the guiding position of Marxism and have not changed. To be serious in Party political life, we must strengthen the theoretical study of Party members and leading cadres, strengthen the scientific belief in Marxism and the lofty ideal of communism, and strengthen the self-confidence in the road, theory, system and culture of socialism with Chinese characteristics. Promoting the effective integration of Marx's theory of Party building with the political life of the party.

\section{References}

[1] Zhu Chunyan. Thought on Maintaining a Serious Political Life within the Party [J]. Journal of Jianghan University (Social Science Edition), 2015, 32(1): 26-30+123.

[2] He Kexiang. On Some Basic Issues about Strengthening and Regulating Intra-Party Political Life [J]. Theory and Reform, 2017(4): 97-106.

[3] Cui Jianzhou. The Experience and Implications of Normalization of Political Life within the Party during Yan’an Period [J]. Studies on Marxism, 2016(4):124-133+160.

[4] Zhou Lisheng, Wang Yuxin. Take a Serious Attitude to the Inner Party Political Life and Construct a Clean Administration [J]. Anti-Corruption and Integrity Culture Studies, 2015(1): 11-15. 